\title{
PENANGANAN SEDIMENTASI DI DAERAH MUARA SUNGAI BAGI KEPENTINGAN PENGOPERASIAN PELABUHAN PERIKANAN
}

\author{
Umi Chodriyah dan Wiwit An Pralampita \\ Peneliti pada Balai Riset Perikanan Laut, Muara Baru-Jakarta \\ Teregistrasi I tanggal: 20 April 2009; Diterima setelah perbaikan tanggal: 2 Mei 2009; \\ Disetujui terbit tanggal: 28 Mei 2009
}

\begin{abstract}
ABSTRAK
Aktivitas pelabuhan merupakan salah satu permasalahan penting untuk diselesaikan baik yang sifatnya teknis pemeliharaan maupun pengelolaan fasilitas pelabuhan, seperti penurunan kualitas lingkungan yang disebabkan oleh sedimentasi. Penanganan sedimentasi (pengendapan) di muara sungai dapat dilakukan dengan pembangunan jetty dan melakukan pengerukkan. Penanganan operasional kapal keruk disesuaikan dengan sifat tanah yang akan dikeruk, kedalaman yang direncanakan, lokasi dan keadaan sekeliling, besar arus dan gelombang, dan faktor yang lain.
\end{abstract}

KATAKUNCI: sedimentasi, muara sungai, pelabuhan perikanan

\section{PENDAHULUAN}

Sungai merupakan suatu aliran yang sangat mudah dan efektif untuk mengalirkan segala macam limbah yang terdapat di sepanjang aliran daerah aliran sungai, disengaja maupun tidak disengaja akan menyebabkan masalah sedimentasi yang serius. Faktor-faktor yang mempengaruhi terjadinya sedimentasi di muara sungai antara lain topografi daerah aliran sungai, iklim, jenis dan tekstur tanah, morfomentrik sungai dan sistem hidrologi, serta energi pasang surut di muara sungai (Tim Ekologi Institut Pertanian Bogor, 1984). Sedimentasi atau pendangkalan pada muara sungai terjadi akibat terhambatnya transportasi sedimen ke laut.

Pengoperasian pelabuhan merupakan salah satu permasalahan penting dan mendesak untuk diselesaikan baik yang sifatnya teknis pemeliharaan maupun pengelolaan fasilitas pelabuhan, seperti penurunan kualitas lingkungan yang disebabkan oleh sedimentasi, pencemaran, dan salinitas perairan pelabuhan.

Tujuan penulisan ini adalah untuk mengetahui penanganan sedimentasi di daerah muara sungai bagi kepentingan pengoperasian pelabuhan perikanan.

\section{PROSES SEDIMENTASI DI MUARA SUNGAI/ PANTAI}

Sedimen adalah endapan yang terjadi di daerah sepanjang pantai laut dan di daerah muara sungai dan sekitarnya. Terdapat 2 jenis bentukkan sedimen yaitu sedimen daerah pantai (akibat dari gerakkan gelombang laut dan arus) dan sedimen daerah muara sungai (akibat dari bawaan sungai, gerakkan gelombang laut dan arus) (Pane, 2008).
Sedimen daerah muara sungai terjadi sebagai akibat adanya bawaan sungai berupa lumpur tersuspensi (dalam bentuk suspensi) dalam jumlah besar, gerakkan gelombang laut, dan air laut pasang yang menghadang di depan muara sungai dan arus laut yang datang dari kiri dan kanan mulut sungai. Proses pembentukkan sedimen di daerah muara sungai banyak dipengaruhi oleh faktor dan yang paling dominan berpengaruh sebagai berikut: (Pane, 2008).

\section{Gelombang Laut}

Perpindahan sedimen paling dominan adalah sejajar pantai atau sepanjang pantai yang memberikan perpindahan sedimen dengan bentuk lintasan seperti garis zig zag sepanjang pantai dan perpindahan sedimen di surf zone. Selanjutnya, sedimen pasir yang terjadi dapat masuk ke daerah muara sungai dan mengendap pada saat gelombang tenang di daerah muara sungai. Kekuatan gelombang (gelombang besar) di pantai berpasir tersebut akan mempengaruhi banyaknya volume sedimen yang masuk daerah muara sungai. Apabila kekuatan arus sungai tidak besar, maka gundukkan endapan di muara sungai semakin besar dan dapat mempersempit mulut sungai, bahkan menutupnya, seperti terjadi di beberapa sungai kecil di pantai utara Jawa (misalnya Jawa Barat dan Jawa Tengah) dan pantai selatan Jawa (misal Daerah Istimewa Yogyakarta dan Jawa Tengah).

\section{Debit Sungai}

Pada sungai yang bawaan atau debit sungainya besar sepanjang tahun dan gelombang laut yang relatif kecil di depan muara, maka akan membentuk sedimen di depan mulut muara sungai yang berbentuk seperti tetesan air ke arah laut, namun dengan gundukkan 
terbesar atau tertinggi terjadi di bagian yang menghadap arah daratan dan semakin merendah atau melandai ke arah laut. Fenomena ini dapat membuat muara sungai maju ke arah laut membentuk delta. Sedimen terjadi merupakan sedimen suspensi dengan ukuran partikel atau butiran beberapa mikron yang selanjutnya akibat gaya tarik antar partikel membentuk Flokon (Fenomena Flokulasi).

\section{Pasang-Surut}

Pada sungai di mana terdapat pasang surut air laut yang cukup tinggi, maka pada keadaan pasang volume air laut yang memasuki sungai berjumlah sangat besar. Air laut tersebut bercampur dengan air sungai di muara sungai. Ketika surut, campuran masa air tersebut menuju laut dengan kecepatan arus surut yang besar, yang berakibat mampu membentuk beberapa muara baru yang lebih kecil dengan sekaligus membentuk sedimen-sedimen suspensi berbentuk seperti pulau memanjang di antara muaramuara baru tersebut.

Pengendapan yang terjadi di daerah di mana aksi gelombang cukup kuat (areas high energy) kemungkinan terdiri atas partikel-partikel besar seperti batu-batu kerikil besar. Partikel-partikel sedimen sejak dibawa atau diangkut dari sumbernya sampai ke pengendapan yang baru, ia akan melalui tingkattingkat kematangannya (maturity). Dengan lamanya waktu perjalanan sedimen, partikel berukuran jenis pasir dari ukuran yang lebih besar berubah menjadi lebih bundar akibat proses kimiawi dan kikisan-kikisan (abrasion).

Gambar 1 tersebut diilustrasikan kondisi alam dari sedimen mengenai tingkat kematangannya sesuai dengan kriteria endapan. Dampak sedimen terhadap aktivitas pelabuhan perikanan secara langsung yaitu terganggunya aktivitas masuk keluar kapal-kapal ikan, sehingga tidak jarang kapal berlabuh atau mendaratkan hasil tangkapannya tidak di dermaga pendaratan atau di luar daerah pelabuhan, demikian juga aktivitas pengisian bahan kebutuhan melaut. Sedangkan pengaruh tidak langsung yaitu menurunnya aktivitas-aktivitas ke pelabuhan lainnya seperti aktivitas pendaratan hasil tangkapan, aktivitas pelelangan ikan, aktivitas pelayanan kebutuhan melaut, dan sebagainya (Pane, 2008). Dampak sedimentasi yang paling dirasakan di pelabuhan perikanan pantai utara Jawa. Hal ini disebabkan sebagian besar pelabuhan perikanan di wilayah ini berada di muara sungai.

\section{PENANGANAN SEDIMENTASI}

Pelabuhan dibuat sedemikian rupa sehingga sedimentasi yang terjadi seminimal mungkin (kalau dapat tidak ada). Untuk itu, di dalam perencanaan pelabuhan ditinjau permasalahan sedimentasi. Proses erosi dan sedimentasi tergantung pada sedimen dasar dan pengaruh hidrodinamika gelombang dan arus. Jika dasar laut terdiri atas material yang mudah bergerak, maka arus dan gelombang akan mengerosi sedimen dan membawanya searah dengan arus. Sedimen yang ditranspor tersebut dapat berupa bed load (menggelinding, menggeser di dasar laut) seperti misalnya pasir atau melayang untuk sedimen suspensi (lumpur dan lempung). Apabila kecepatan arus berkurang (misalnya di perairan pelabuhan), maka arus tidak mampu lagi mengangkat sedimen, sehingga akan terjadi sedimentasi di daerah tersebut. Sedimen yang ada di daerah pantai dapat berupa pasir atau sedimen suspensi. Sedimen suspensi berasal dari sungai-sungai yang bermuara di pantai (Triatmojo, 1986).

Arah perkembangan kematangan

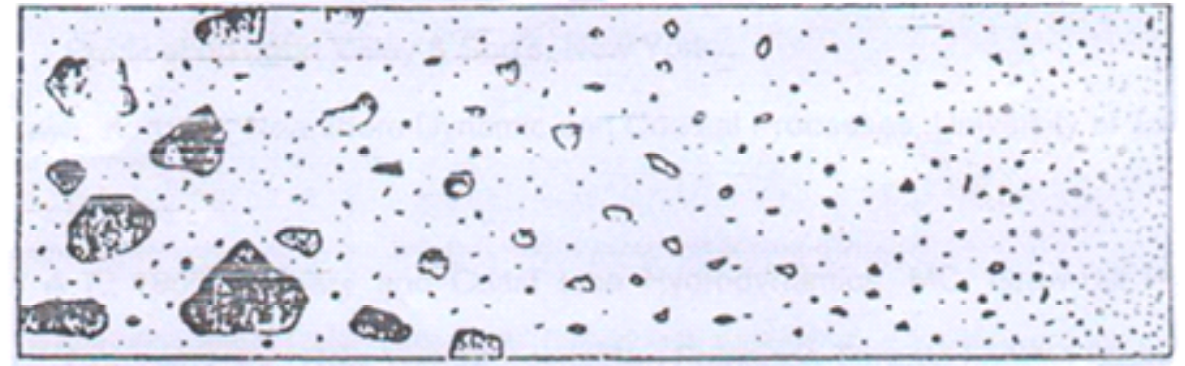

Isi dari tanah liat menurun

Meningkatnya keseragaman jenis ukuran

Bentuk bulatannya butiran meningkat (lebih bulat)

Gambar 1. Kematangan sedimen. 
Pengaruh pasang surut sangat besar pada muaramuara sungai (estuary). Jadi apabila suatu pelabuhan dibangun pada muara-muara sungai, ada 2 hal yang perlu diperhatikan, yaitu:

a. Navigasi melalui muara cukup aman.

b. Pengendapan (sedimentasi) cukup kecil.

Kedua hal tersebut bertentangan. Di satu pihak keamanan navigasi membutuhkan mulut pelabuhan besar, tetapi hal ini menyebabkan kecepatan arus rendah, jadi mempermudah terjadinya sedimentasi. Sebaliknya mulut pelabuhan yang kecil mengurangi keamanan navigasi, tetapi menghindarkan terjadinya pengendapan. Jadi dicari besaran nyata kedua permasalahan tersebut.

Contoh masalah sedimentasi di pelabuhan adalah pelabuhan Mandara Permai. Pelabuhan ini merupakan pelabuhan untuk rekreasi yang terletak di pantai sebelah barat Tanjung Priok di sepanjang Pantai Cengkareng. Di sekitar lokasi pelabuhan banyak sungai yang membawa sedimen suspensi. Untuk menghalangi masukknya sedimen suspensi ke perairan pelabuhan maka dibuat pemecah gelombang sepanjang $930 \mathrm{~m}$. Pembuatan pemecah gelombang sepanjang itu supaya sedimen suspensi yang ada di daerah pantai tidak masuk ke kolam pelabuhan. Air yang masuk di pelabuhan adalah air laut yang jernih. Untuk mengurangi masalah sedimentasi di pelabuhan, maka layout pemecah gelombang dibuat sedemikian rupa, sehingga sedimen sulit masuk ke perairan pelabuhan. Dalam Gambar 2a, mulut pelabuhan dibuat tidak menghadap ke arah transport sedimen sepanjang pantai. Sedimen yang bergerak ke kiri terhalang oleh pemecah gelombang dan mengendap di tempat tersebut. Pada Gambar 2b, sedimen suspensi dari sungai menyebar ke pantai. Apabila terjadi arus dari kanan sedimen tesebut akan terbawa ke kiri. Apabila mulut pelabuhan menghadap ke kanan sedimen akan mudah masuk ke pelabuhan dan menyebabkan terjadinya sedimentasi. Karena sifat sedimen suspensi yang mudah terbawa arus, maka sedimen tersebut dapat masuk ke pelabuhan, meskipun mulut pelabuhan telah dibuat menghadap ke kiri, tetapi jumlahnya lebih sedikit dibanding apabila mulut menghadap ke kanan (Triatmojo, 1986).

Hasil penelitian Sugeng \& Atmojo (2008) menunjukkan bahwa sumber sedimen yang mengakibatkan pendangkalan muara Sungai Pengkol (Kabupaten Jepara) adalah berasal dari aliran sungai, dan dari transportasi sedimen menyusuri pantai. Sumber yang pertama jauh lebih besar dibanding sumber kedua, dan bahkan kadang-kadang memberikan masukkan sedimen ke laut.
Pengembangan atau pembangunan suatu pelabuhan tentunya mempunyai dampak terhadap lingkungan atau dapat merubah kondisi lingkungan aslinya. Kondisi pasang surut sangat besar pengaruhnya pada muara-muara sungai (estuary) seperti di Astanajapura, Cirebon (Raharjo \& Faturahman, 2008). Kondisi arus di perairan Astanajapura memperlihatkan bahwa selain akibat perubahan muka air (pasang surut), pengaruh angin permukaan cukup berperan dalam pembentukkan pola arus di daerah ini. Gerakkan air akibat pasang surut yang terjadi di perairan Astanajapura ini menjadi arus berputar (rotating movement) yang disebut vortex (Ealze). Hal ini dapat terjadi akibat arus dominan yang bergerak dari arah timur laut ke barat daya dan pengaruh pasang surut serta membentur Tanjung Dleweran. Perubahan garis pantai yang terjadi di perairan Astanajapura yaitu majunya garis pantai atau penambahan lahan terjadi akibat proses sedimentasi cukup intensif yang dipengaruhi oleh faktor oseanografi serta klimatologi.

Salah satu bangunan penanganan sedimentasi di muara sungai adalah jetty yaitu sepasang bangunan yang dibangun di kedua sisi mulut muara sungai (jetty kanan dan jetty kiri) dan posisinya tegak lurus ke arah atau menjorok ke laut. Tujuannya adalah menahan laju bahan sedimen yang dibawa oleh arus laut sepanjang pantai dari arah kanan jetty kanan dan dari arah kiri jetty kiri, yang mengakibatkan bahan sedimen mengendap atau menumpuk di kanan jetty kanan dan di kiri jetty kiri, sehingga daerah muara sungai di antara kedua jetty terbebas dari pengaruh sedimen tersebut (daerah yang diharapkan dan dimanfaatkan) seperti pada Gambar 3.

Untuk memelihara kedalaman suatu kolam atau alur pelayaran atau alur sungai (maintenance dredging) yang disebabkan adanya proses pergerakkan dan pengendapan lumpur (sediment transport), maka dilakukan pengerukkan. Di Indonesia pelabuhanpelabuhan yang memerlukan pengerukkan pemeliharaan yang besar adalah Belawan, Palembang, Tanjung Priok, Surabaya, dan Pontianak. Hal ini diakibatkan letak pelabuhan-pelabuhan tersebut di dekat muara sungai yang pada akhir-akhir ini banyak mengalami erosi (Kramadibrata, 1989).

Menurut Kramadibrata (1989), pengerukkan aluralur pelayaran banyak ditentukan berdasarkan pada keadaan tanah (soil condition). Tanah yang dikeruk ini dapat berupa lumpur, pasir, dan lumpur atau batu karang. Pada umumnya tanah-tanah pantai di Indonesia berupa lumpur atau lumpur berpasir (alluvial). Tipe kapal keruk yang dipergunakan disesuaikan 


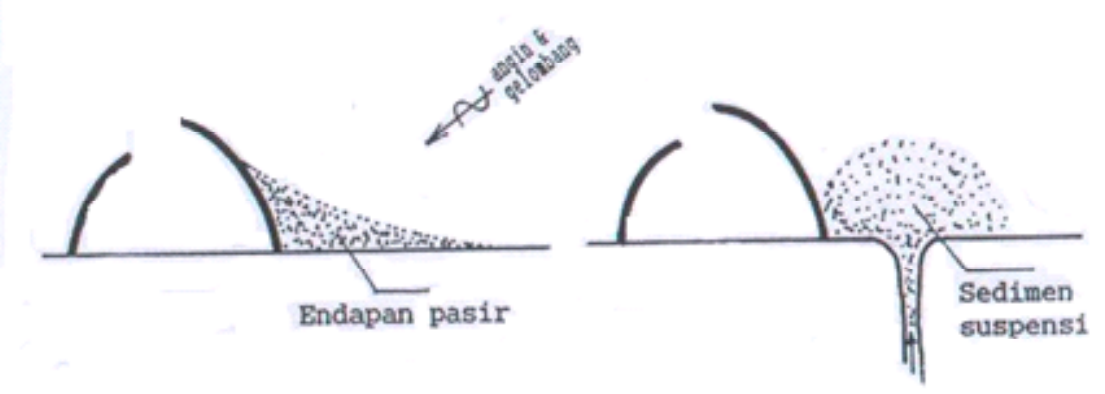

Gambar 2. Layout pemecah gelombang terhadap tinjauan sedimentasi.

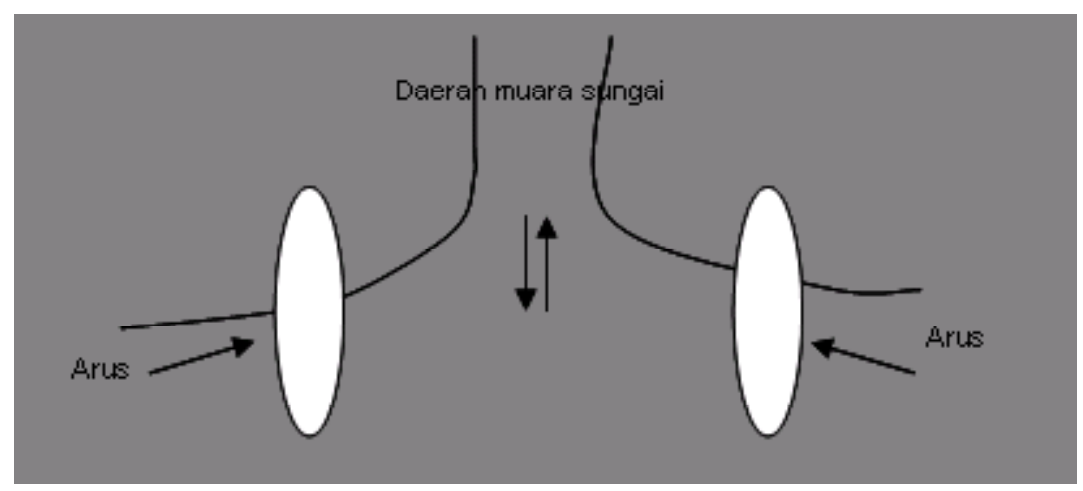

Gambar 3. Layout bangunan jetty di daerah muara sungai.

dengan keadaan tanah. Bagi tanah batu atau batu karang, mula-mula batu karang tersebut perlu diledakkan dengan dinamit untuk kemudian diambil dengan grap atau dipper. Contoh di Indonesia yaitu alur pelayaran Pelabuhan Benoa, Bali. Sedangkan untuk tanah lumpur digunakan suction dredger atau hopper suction dredger. Untuk tanah berpasir digunakan cutter suction dredger. Dengan pengerukkan alur dan kolam pelabuhan, maka stabilitas tanah lingkungan daerah pengerukkan tersebut perlu diamankan dan diperhitungkan (Kramadibrata, 1989).

\section{KESIMPULAN}

1. Penanganan sedimentasi (pengendapan) di muara sungai dapat dilakukan dengan pembangunan jetty dan melakukan pengerukkan.

2. Penanganan operasional kapal keruk disesuaikan dengan sifat tanah yang akan dikeruk, kedalaman yang direncanakan, lokasi dan keadaan sekeliling, besar arus dan gelombang, dan faktor yang lain.

\section{PERSANTUNAN}

Kegiatan dari hasil riset perkembangan pukat cincin mini setelah kolapnya pukat cincin besar di bagian pantai utara Jawa, T. A. 2007 di Balai Riset Perikanan Laut, Muara Baru-Jakarta.

\section{DAFTAR PUSTAKA}

Kramadibrata, S. 1989. Perencanaan Pelabuhan. Ganexa Exact. Bandung. 480 pp.

Pane. 2008. Bahan Kuliah Teknik Kepelabuhanan. Jurusan Pemanfaatan Sumber Daya Perikanan. Fakultas Perikanan dan IImu Kelautan. Institut Pertanian Bogor. Bogor.

Raharjo, P. \& A. Faturachman. 2008. Estimasi Kecepatan Sedimentasi di Perairan Astanajapura, Kabupaten Cirebon, Jawa Barat. Pusat Penelitian dan Pengembangan Geologi Kelautan. Bandung.

Triatmojo, B. 1986. Perencanaan Pelabuhan. Beta Offset. Yogyakarta. 299 pp.

Tim Ekologi IPB. 1984. Ecologycal Aspects of Segara Anakan in Relation to Its Future Management. Institute of Hydraulic Engineering and Faculty of Fisheries. Institut Pertanian Bogor. Bogor.

Sugeng, W. \& W. Atmojo. 2008. Influks sedimen dan laju sedimentasi di muara Sungai Pengkol Jepara. Majalah IImu Kelautan. 16: p. 233-238. Jurusan Ilmu Kelautan Universitas Diponegoro. Semarang. 